\title{
1. Certainty versus flexibility in the conflict of laws
}

\section{Kermit Roosevelt III*}

\section{INTRODUCTION}

Certainty versus flexibility in the conflict of laws: in America, Willis Reese, the Reporter for the Second Restatement, offered a thorough meditation on the subject in 1972. ${ }^{1}$ Commentators too numerous to count have followed. ${ }^{2}$ Outside the United States, discussions can be traced back thousands of years, all the way to Aristotle, if not further. ${ }^{3}$ Could there be anything new to say?

Perhaps. At the least, I hope it is possible to offer not just the standard observations or a summary of competing views, but an assessment geared to a particular moment this moment - in the development of American conflict of laws. ${ }^{4}$ Section 2 of this chapter sets the theoretical framework for the discussion. It tries to clarify both what is at stake in the choice between rules and standards, or certainty and flexibility, and how the two goals or sets of goals can be pursued simultaneously, or at least sequentially.

Section 3 turns to the real world. It describes the evolution of American choice of law in terms of the theoretical framework developed in the first part and, by way of

* Professor of Law, University of Pennsylvania Law School. Reporter, Third Restatement of Conflict of Laws. The views expressed in this chapter are those of the author alone.

1 Willis L.M. Reese, Choice of Law: Rules or Approach, 57 Cornell L. Rev. 315 (1972). Before him, the Reporter for the First Restatement, Joseph Beale, had noted the tradeoff. See Joseph Beale, A TREATise on THE CONFLiCT OF LAWs § 4.13 (1935).

2 For a brief sampling, see, for example, J.J. Fawcett, Policy Considerations in Tort Choice of Law, 47 M.L.R. 650 (1984); Alan Reed, The Anglo-American Revolution in Tort Choice of Law Principles: Paradigm Shift or Pandora's Box?, 18 Ariz. J. Int'l \& Comp. L. 867, 877-78 (2001); James J. White, Ex Proprio Vigore, 89 Mich. L. Rev. 2096, 2137 (1991) Edgar H. Ailes, Substance and Procedure in the Conflict of Laws, 39 Mich. L. Rev. 392, 415 (1941); Larry Kramer, On the Need for a Uniform Choice of Law Code, 89 Mich. L. Rev. 2134, 2137 (1991); Courtland H. Peterson, Private International Law at the End of the Twentieth Century: Progress or Regress?, 46 Am. J. Comp. L. 197, 212 (1998).

3 See Symeon C. Symeonides, Oregon's New Choice-of-Law Codification for Tort Conflicts: An Exegesis, 88 Or. L. Rev. 963, 1040 (2010) (citing Aristotle's Nicomachean Ethics as an example of "the tension between the need for legal certainty and predictability, on the one hand, and the desire for flexible, equitable, individualized solutions on the other").

4 Reese's article, as I will discuss, was also geared toward a particular moment: the writing of the Second Restatement. See infra section 3.4. In a sense, then, this chapter seeks to update his. 
comparison, takes a brief look at the European experience. Section 4 tries to bring the two preceding parts together: it asks what lessons we can draw from theory and history to guide us going forward.

\section{THE THEORETICAL PERSPECTIVE}

The first task is to articulate what the distinction between certainty and flexibility is. There are, in fact, several related but not entirely consistent distinctions at work. Perusing the literature, one can find discussions of certainty versus flexibility, ${ }^{5}$ of rules versus approaches, ${ }^{6}$ of territoriality versus policy analysis, ${ }^{7}$ of rules versus standards 8 and of traditional versus modern methods. ${ }^{9}$ Layering these distinctions atop each other gets us to American paradigm cases: the First Restatement is inflexible, ${ }^{10}$ territorial, traditional and rule-based; while the Second Restatement is flexible, policy-based, modern and standard-like. Generally speaking, the distinctions mean roughly the same thing and the discussion of this chapter will work regardless of which is chosen. ${ }^{11}$ (I will, however, offer a slightly different understanding of the Second Restatement.) But it is worth spending a little time to look more closely at the different ways in which to draw the distinctions in order to get a clearer sense of what is at stake.

\subsection{Certainty and Flexibility}

What does it mean to say that a choice of law system provides certainty? To take the narrowest understanding, and the one most easily opposed to flexibility, certainty

5 See, for example, Courtland H. Peterson, Private International Law at the End of the Twentieth Century: Progress or Regress?, 46 Am. J. Comp. L. 197, 212 (1998) (describing "the tension between the goals of certainty and flexibility").

6 See, for example, Reese, supra note 1.

7 See, for example, Robert Sedler, The Territorial Imperative: Automobile Accidents and the Significance of a State Line, 9 Duq. L. Rev. 394, 402-07 (1971) (suggesting that policy-oriented analysis makes territorial contacts irrelevant).

8 See, for example, Erin Ann O'Hara, Economics, Public Choice, and the Perennial Conflict of Laws, 90 Geo. L. J. 941, 950 (2002) (distinguishing between rules and standards).

9 See, for example, John Bernard Corr, Modern Choice of Law and Public Policy: The Emperor Has the Same Old Clothes, 39 U. Miami L. Rev. 647, 648 (1985) (stating that "modern approaches substantially supplanted the traditional rules"). Sometimes multiple phrasings are run together. See, for example, Giesela Rühl, Methods and Approaches in Choice of Law: An Economic Perspective, 24 Berkeley J. Int'l L. 801, 829 (2006) ("Should choice of law rules primarily be designed to provide for legal certainty or should they rather allow for flexibility? In other words: should choice of law provisions be framed as rules or as standards?"); Herma Hill Kay, Currie's Interest Analysis in the 21st Century: Losing the Battle, but Winning the War, 37 Willamette L. Rev. 123, 128 (2001) (noting theme of "the tension between the goals of certainty and flexibility, and the co-existence of choice-of-law rules, and choice-of-law 'approaches"'); Corr, supra, at 648 (referring to "modern approaches" and "traditional rules").

10 Inflexible is not the same thing as certain, as discussed below.

11 I take the dichotomies to be more or less interchangeable in large part because I believe that none of them is really about what it claims to be. Each is used, I will argue, as a proxy for a distinction between two sets of values. See infra section 2.5 . 
implies a lack of judicial discretion. The system provides a single answer from which the judge cannot deviate. A flexible system, by contrast, allows judicial discretion: if cases come along to which the system-mandated answer seems incorrect, a flexible system allows them to be avoided. ${ }^{12}$

This formulation is correct as far as it goes, and probably helpful in some ways; but it is also worth noting how narrow it is. Certainty is usually offered as one of a constellation of related virtues: uniformity, predictability and simplicity are common companions. Yet a system that allows no discretion could be quite complicated (the First Restatement was). If sufficiently complicated, it would lose predictability even if judges were able to follow it correctly. If they were not, it would lose uniformity and, on some understandings, certainty as well. ${ }^{13}$ And, of course, a simple and certain system (e.g., always apply forum law) might not deliver uniformity or predictability or at least, not predictability at the time of the relevant primary conduct.

Flexibility, in this formulation, is also narrow. It means that judges have some discretion. The system does not prescribe a single answer. It might leave open a range of possibilities, about which different decision makers might disagree without any of them being clearly correct or incorrect. (That is a flexible system that will be non-uniform and unpredictable. Probably, as discussed below, it involves standards or an approach; probably, that is, it tells judges to apply a concept without clear edges or to weigh several factors. $)^{14}$ Or it might direct a clear answer, but have a proviso granting judges the authority to deviate from that answer in appropriate exceptional cases. (This system will still lack uniformity and predictability if judges cannot agree on which cases merit invocation of the exception, but it will likely be more uniform and predictable than the standard or approach-based system. It is probably a rule and exception system.)

Like certainty, flexibility is generally taken to have certain virtues - it is usually associated with a fewer number of arbitrary outcomes than rigid systems. (What it means for a choice of law decision to be arbitrary or sensible is important and will be discussed later. For now, I mean to suggest only that while some decisions may be clearly correct within particular systems, they may nonetheless appear arbitrary measured against the criteria that sensibly allocate regulatory authority among co-equal sovereigns.) That might be true - it is probably true of the rule-and-exception system described in the preceding paragraph - but it is not necessarily so. A flexible system that demands a lot of judges might produce arbitrary results, especially if it fails to explain itself adequately to its users or if judges lack experience in applying it. ${ }^{15}$

12 See, for example, Alex Mills, The Identities of Private International Law: Lessons from the U.S. and EU Revolutions, 23 Duke J. Comp. \& Int'l L. 445, 449 (2013) (discussing "balancing predictability and the benefits of legal certainty against a flexibility which might lead to more appropriate results in particular cases").

13 If the judge cannot figure out the correct answer, one might reasonably call the outcome uncertain. But if we understand certainty as a lack of discretion, the fact that a system is too hard for judges to apply correctly does not take away from its certainty, at least not absent conscious manipulation by judges.

14 See infra section 2.2.

15 Both these things, I believe, can be said of the Second Restatement. 
So describing a system as certain or flexible still doesn't tell us much about it - not as much as it is generally taken to, at any rate. Systems that provide certainty might lack uniformity, predictability or simplicity; flexible systems might still produce arbitrary results. The certain versus flexible distinction tells us something about what the judge's decision-making process is like - specifically, whether it involves the exercise of discretion or not; but it tells us very little about the system as a whole.

\subsection{Rules and Standards; Rules and Approaches}

With the distinction between rules and standards or rules and approaches, we take a different perspective than that offered by the certainty/flexibility distinction. Rules versus standards or rules versus approaches tells us something about the form of the system, rather than the experience of a judge applying it. A rule, as Willis Reese put it, is "a formula which once applied will lead the court to a conclusion."16 Reese contrasted rules with what he called "an approach," meaning "a system which does no more than state what factor or factors should be considered in arriving at a conclusion." 17 A rule, we could say, tells judges what the answer is in the sense of which state's law should be selected. An approach tells judges what the answer is too, but in a very different sense: it tells them the value or values they are supposed to maximize, but not which state's law will do so. ${ }^{18}$ A standard similarly tells judges the value they are supposed to implement, but requires additional work to identify a particular state's law. ${ }^{19}$

The difference between a standard and an approach is hard to make out and I will treat the two as essentially equivalent. One might say that putting several standards together generates an approach - the Second Restatement puts together standards including the needs of the interstate and international systems, respect for state policies and the protection of justified expectations in order to generate its approach. But what

16 Reese, supra note 1 , at 315 .

17 Ibid.

18 Where a rule might say "use the law of the place of injury," for instance, an approach might say "use the law of the state with the most significant relationship to the issue."

19 The fact that applying a rule is (generally) mechanical and straightforward while applying a standard requires additional work is probably the best practical distinction. Gisela Ruhl describes the difference as follows:

In economic theory, rules are usually defined as simple and clear legal norms whose precise content is promulgated prior to individual's behavior. In contrast, standards are usually understood as unclear and fuzzy legal norms whose precise content is determined after the relevant individuals' behavior has taken place.

Gisela Ruhl, Methods and Approaches in Choice of Law: An Economic Perspective, 24 Berkeley J. Int'l L. 801, 831 (2006). Ruhl connects the rules/standards distinction to that between certainty and flexibility: "The discussion about whether choice of law should provide for legal certainty or flexibility finds a close relative in the law and economics literature: the rules versus standards debate." Ibid. As the text discusses, I do not include simplicity or clarity as a necessary feature of a rule: rules can be complex and difficult to follow. But since such rules sacrifice some of the significant values of rules (uniformity, predictability, and ease of application), they tend to be rare. 
the concatenation of Section 6 factors produces is also another standard: the most significant relationship. And most standards, even if set out as single requirements, will require the consideration of multiple factors. In the classic example of a 65 miles per hour speed limit versus a "reasonable" speed, several factors will go into the reasonableness determination.

In the choice of law context, rules and standards typically differ in terms of the values they promote. The Second Restatement's Section 6 factors provide a useful way of thinking about this: some tend to be promoted by rules and others by standards. The needs of the interstate and international system (if understood as a respect for the authority of other sovereigns), the promotion of state policies, the protection of justified expectations and the basic policies underlying particular fields of law are all values more typically associated with standards; while certainty, predictability, uniformity and ease in application are values more typically associated with rules. ${ }^{20}$

Again, however, the connection is contingent and may vary over time. A rule could be complicated and so difficult to apply that it undermined uniformity and predictability. Conversely, a rule could - if it picked the "right" answer in every case - do a perfect job of balancing the regulatory authority of co-equal sovereigns (what I understand as the basic choice of law task and a summary of the first three Section 6 factors). A standard might not require much work to implement; but it might also, if it is the wrong standard, do a bad job of getting judges to the right answers. ${ }^{21}$ There is also the possibility of hybrids: a rule might use what Symeon Symeonides has called "soft" connecting factors or might include an escape provision designed to handle cases in which the result directed by the rule seems inappropriate. ${ }^{22}$ And an approach might have what looks very much like rules built into the analysis: "in a false conflict, apply the law of the only interested state" is quite rule-like. ${ }^{23}$

Good rules, in short, will tend not to produce very many arbitrary results; good standards will tend to be relatively simple and predictable. As each gets better, they

20 See, for example, Reese, supra note 1, at 315-316.

21 The idea that judges should decide which of two contending laws is "better" is a standard that has the potential to be simple, if it collapses to a preference for forum law, but also produce bad answers. It seemed to do that in some cases, maybe most notably Allstate Insurance Co. v. Hague, 289 N.W.2d 43 (Minn. 1979), aff'd 449 U.S. 302 (1981). See also Milkovich v. Saari, 203 N.W.2d 408 (1973) (using "better law" criterion to justify advancing the forum's "concept of justice and equity"). There are also some more promising examples of the approach, though these tend to downplay the better law factor. See, for example, Jepson v. General Casualty Co. of Wisconsin, 513 N.W.2d 467 (Minn. 1994) (stating that "[s]ometimes different laws are neither better nor worse in an objective way, just different").

22 See generally Symeon C. Symeonides, The American Choice-of-Law Revolution: PASt, PRESEnT, AND Future 411-19 (2006).

23 How to decide whether a case presents a false conflict is a separate question, but that analysis too can be made rule-like: "a state is interested if and only if use of its law would benefit a domiciliary" looks very much like a rule. It is a bad rule, of course, and not one that should be used in the decision of actual cases, but if one were trying to simplify the analysis to demonstrate how it works conceptually, one might be forgiven for offering such a rule for that purpose. See Brainerd Currie, SELECTED EsSAYS ON THE CONFLiCT OF LAWS 89 (1963) (positing "a quite selfish state"). 
converge. ${ }^{24}$ Thus, the idea that there is an inevitable choice or tradeoff between the two is at best oversimplified and at worst simply false. As Peter Hay and Robert Ellis put it:

The perception of a gap, of something irreconcilable, between legal systems with rules and those following approaches for the determination of the applicable law is itself dated. Its articulated or intuitive basis is, on the one hand, that rules are rigid, (therefore bad on principle or, at best, of limited utility in a world of differentiated fact patterns and various constellations of interests) and, on the other hand, that approaches will result in, and indeed invite, ad hoc decision making, "Khadi-justice." Both views misstate today's situation, if indeed they were ever entirely correct. $^{25}$

\subsection{Territoriality versus Policy Analysis}

Another common distinction in choice of law scholarship is between territorial systems and those that engage in policy analysis. ${ }^{26}$ Again, generally speaking, the line drawn here is considered to be similar to that drawn by the certainty/flexibility distinction or the rules/standards one. Territoriality is considered to be rule based and certain, with the associated virtues and vices; while policy analysis is flexible and approach based. Again, however, the connections are contingent and weaker than generally assumed: the distinction does not have the significance or stability it is usually assigned.

The main reason the distinction breaks down is that no current system is territorialist in the sense in which the First Restatement was. Joseph Beale's analysis was based on the premise that law was, by its very nature, territorial. ${ }^{27}$ The rules he derived from this premise were, in his view, the only possible ones. They were statements of the way things had to be. That sort of territorialism can meaningfully be distinguished from policy analysis: there is no need to ask what states want or are trying to achieve, because the answer comes from features of law that are beyond the power of states to change. ${ }^{28}$ But in the modern world, it is clear that territoriality is not a necessary feature of law. States can, if they want, project their regulatory authority beyond their

24 In modern practice, most systems have features of both rules and standards or approaches. Most codifications have escape clauses. See generally Symeon C. Symeonides, CoDIFYING CHOICE OF LAW AROUND THE WorLD (2014). And many approaches have rule-like resolutions of certain categories of cases, such as New York's Neumeier rules. See Neumeier v. Kuehner, 286 N.E.2d 454 (N.Y. 1972).

25 Peter Hay and Robert B. Ellis, Bridging the Gap Between Rules and Approaches in Tort Choice of Law in the United States: A Survey of Current Case Law, 27 Int'1 Law. 369, 394-95 (1993).

26 See, for example, Comment: Conflict of Laws-Two Case Studies in GovernmentalInterest Analysis, 65 Colum. L. Rev. 1448, 1449 (1965) (describing how "[t]he Babcock decision shifted the focus of the judicial choice-of-law inquiry away from territorial principles to policy justifications underlying diverse rules of law ...").

27 See Walter Wheeler Cook, The Logical and Legal Bases of the Conflict of LaWs 6-7 (1942) (describing Beale's methodology).

28 In one sense, this seems like a rejection of policy analysis. But in another sense, it is a transcendence of it. The point of policy analysis, I will suggest, is to get "right" answers in terms of sensible allocation of regulatory authority among co-equal sovereigns. But if only one answer is possible, it is necessarily also "right" - or at the least, there is no preferable alternative that could be adopted instead. 
borders in at least some cases. No modern territorial system is based on the belief that things can't be different. Territorialism is, in fact, a policy choice. ${ }^{29}$

What kind of a policy choice is it? There are two possible answers. First, a territorial solution to a particular choice of law problem, or a narrow territorialist rule, might well be based on an analysis of the policies underlying a particular law and an assessment of the relative interests of relevant states - exactly the sort of policy analysis put forward as an antidote to the First Restatement. Sometimes the policies underlying laws are territorial. ${ }^{30}$

Second, and equally important, a territorial solution to a particular problem, or even a broader territorialist system, might be based on policy considerations such as simplicity, predictability, uniformity and ease of application. Those policies are different in some ways from policies such as the discouragement of negligent driving, but they are still state policies that can be used to answer choice of law questions. (As I will note, they are perhaps better suited to designing choice of law systems than to answering particular questions, but designing a system implies answers to those questions.)

\subsection{Traditional versus Modern}

One final way of drawing the line is the distinction between traditional and modern choice of law theories. Here again, the idea is that traditional choice of law is territorialist and rule based, while modern systems are flexible approaches rooted in policy analysis. ${ }^{31}$ But again, the distinction is contingent and increasingly inaccurate. Because the First Restatement's incarnation of territoriality in torts gave decisive

29 The strange thing about territoriality is that it sometimes seems to make this policy choice not only for a state's own law, but for the law of other states as well - territorialist state A sometimes seems, that is, to say not only that A law is territorially limited, but that the law of all other states is as well. But state A does not have the authority to declare policy for other states, or to determine the scope of their laws. See Kermit Roosevelt III, Choice of Law in Federal Courts: From Erie and Klaxon to CAFA and Shady Grove, 106 N.W.U. L. Rev. 1, 24-25 (2012). Consequently, territorial choice of law may be best understood as a decision to assign priority to a state's law based on territorial connecting factors rather than announcing a territorial limit to the scope of that law.

30 In modern theory, territorial connecting factors tend to be taken as especially significant for rules deemed conduct regulating. See generally Symeonides, supra note 22, at 123-37; see also Note, Comparative Impairment Reformed: Rethinking State Interests in the Conflict of Laws, 95 Harv. L. Rev. 1079, 1091 (1982) ("Although policy-oriented theorists have seen policy analysis and territoriality as mutually exclusive approaches to conflict-of-laws adjudication, consideration of territorial contacts is in fact a means of assessing the existence and quantum of state interests.").

31 See, for example, Christopher A. Whytock, Myth of Mess? International Choice of Law in Action, N.Y.U. L. Rev. 725 (noting that "[b]eginning in the 1960s, with the onset of the so-called 'American choice-of-law revolution,' a growing number of states began replacing the First Restatement method with one of several 'modern' methods"); Stewart E. Sterk, The Marginal Relevance of Choice of Law Theory, 142 U. Pa. L. Rev. 949, 987 (1994) (suggesting that "modern choice of law theory" gives judges discretion); Katherine Florey, State Courts, State Territory, State Power: Reflections on the Extraterritoriality Principle in Choice of Law and 
significance to a single event - the occurrence of injury (the last act rule) ${ }^{32}$ - its resolution of tort conflicts naturally took the form of rules designed around that crucial single factor. Policy-based analysis, partially in response, took the form of arguments that more connecting factors needed to be considered and might be of different weight in different kinds of cases. ${ }^{33}$ Because of that, policy analysis in its early forms tended to look more like an approach.

We can, however, imagine a flexible or approach-style territoriality: the master principle remains that the law of the state where a tort occurred governs; but in deciding where it occurred, a court is to balance the connecting factors - the place of conduct, the place of injury, the parties' domiciles (since that may be where the effect of the injury is felt) and so on. This would be something like the center of gravity approach to conflicts. ${ }^{34}$ And conversely, we can imagine a rule-based approach to policy analysis. "In guest statute cases, where the parties come from one state, use the law of that state to determine whether a passenger can sue a driver" is a rule, ${ }^{35}$ but one crafted in order to respect state policies and interests.

If "modern" means standard-like, then "modern choice of law" is like "modern art": not contemporary, but the product of a particular time period and theoretical stance. ${ }^{36}$ Contemporary (as opposed to modern) choice of law is often rule based. This is overwhelmingly the case abroad; ${ }^{37}$ and even if one confines the analysis to the United States, the most significant recent moves are probably the codifications adopted by Louisiana and Oregon. All of these codifications give a significant role to territorial factors. ${ }^{38}$ Perhaps more striking, modern thinking, as developed in modern approaches, turns out to have a lot of territoriality in its application. David Cavers' "principles of preference" provide one example: after a time as a Realist critic of the First Restatement, Cavers ended by offering empirically derived rules for tort cases that reflected what he thought readers might deem "a territorialist bias." 39 And empirical analysis suggests that California's "comparative impairment" resolution of true conflicts - perhaps the most ambitious attempt to find "right answers" to choice of law

Legislation, 84 Notre Dame L. Rev. 1057, 1068 (2009) (describing authority of courts under "traditional" and "modern" choice of law).

32 See, for example, Harold L. Korn, The Choice of Law Revolution: A Critique, 83 Colum. L. Rev. 772, 778-79 (1983) (discussing last act rule).

33 For instance, policy analysis suggests that the parties' domicile might matter, and might matter more with loss-allocating rules than with conduct-regulating rules.

34 See, for example, Auten v. Auten, 124 N.E.2d 99 (N.Y. 1954) (choosing law to govern a contract by identifying the transaction's center of gravity).

35 In fact, it is one of New York's Neumeier rules.

36 See, for example, Arthur C. Danto, After the End of ART: CONTEMPorary ART AND THE PALE OF HiSTORY 11 (1997) (noting that the descriptor "modern" "had a stylistic meaning and a temporal meaning"); Gary T. Schwartz, Medical Malpractice, Tort, Contract, and Managed Care, 1998 U. Ill. L. Rev. 885, 900 (noting that "'modern art' was at some point supplanted by "contemporary art"').

37 See generally Symeonides, Codifying ChOICE of LAW Around THE World: AN INTERNATIONAL COMPARATIVE ANALYSIS (2014).

38 See Symeonides, supra note 37, at 53 (noting that the lex loci delicti rule "continues to be the dominant rule in the codifications of the last 50 years").

39 David Cavers, The Choice of LAW Process 134-35 (1965). 
problems - ends up in practice producing a large number of territorial outcomes. ${ }^{40}$ Thus, while it is true that traditional American systems were territorial and rule based, ${ }^{41}$ it is simply not the case that more recent systems have rejected those features.

\subsection{Conclusion}

The preceding sections aimed to demonstrate that the distinctions traditionally used to create a taxonomy of choice of law systems are not as robust as commonly thought. They are widely understood to designate particular clusters of theories and values, and are useful for that purpose; but the connections between the distinctions and these values are contingent and often overstated. A better way to approach the issues is probably to start with the values themselves.

What are the relevant values in designing a choice of law system? We may begin with the list provided by the Second Restatement. Section 6 instructs courts that the factors relevant to a choice of law decision include the needs of the interstate and international systems, the policies of interested states and their relative interests in particular issues, the protection of justified expectations, the basic policies underlying the particular field of law, certainty, predictability, uniformity and ease in application. ${ }^{42}$

What exactly is meant by these factors, and the extent to which they overlap or repeat, is not entirely clear. (The explanation the Second Restatement gives of the needs of the interstate and international system - that it requires "regard for the needs and policies of other states and of the community of states" 43 - makes it sound like it is largely taken care of by considering the relative interests of relevant states. ${ }^{44}$ ) But they can generally be separated into two categories: factors related to whether the choice of a state's law is sensible in a particular case (what I will call "right answer" factors) and factors related to whether a choice of law system is desirable (what I will call "systemic" factors). ${ }^{45}$ Indeed, the Second Restatement itself seems to boil things

40 See Michael H. Hoffheimer, California's Territorial Turn in Choice of Law, 67 Rutgers U. L. Rev. 167 (2015).

41 Again, looking beyond the United States complicates the picture. The Italian statutists developed a system that did not rely on territorialist premises or broad rules but rather - much like Currie's interest analysis - required analysis of particular statutes to determine whether they were "real" (hence territorial in scope) or "personal" (and hence tied to persons rather than territory). See Cavers, supra note 39, at 2.

42 See Restatement, Second § 6(b).

43 See Restatement, Second, $\$ 6$, cmt. d.

44 Alternatively, one court found that the way to promote the needs of the interstate and international systems was not to choose a particular state's law but simply to adopt the Second Restatement. Phillips v. General Motors, 995 P.2d 1002 (Mont. 2000).

45 Respect for the sovereignty of other states and for the policies of interested states, the basic policies underlying the field of law, and the protection of justified expectations (factors a-e) are primarily right answer factors. Certainty, predictability, uniformity, and ease of application (factors $\mathrm{f}$ and $\mathrm{g}$ ) are primarily systemic factors. Even here the dichotomy does not entirely hold: states might have policies in favor of predictability and uniformity that are reflected in or enter into their substantive law. This is not very obvious in torts (though an "in this state" limit might be understood as an attempt to promote those values) but can easily be seen in contracts. Party autonomy is a substantive value in contract law, but in the choice of law 
down to this distinction in Comment d to Section 5. "The policies reflected by Conflict of Laws rules," it tells readers, "are essentially of two kinds: those which underlie the particular local law rules at issue and those which underlie multistate situations in general." 46

Speaking generally, then, we can say that a good choice of law system will have two features. First, it will deliver sensible rather than arbitrary answers to choice of law questions in individual cases - it will do a reasonably good job of getting the right answer to those questions. ${ }^{47}$ Second, it will deliver those answers in an easy, uniform and predictable way, allowing parties to plan their conduct and reducing costs for litigants and judges. The general import of the distinctions drawn above (particularly when they are set up as opposed values, as the "versus" suggests) is that in the real world, ${ }^{48}$ there is a tension between these two features: sensible answers seem to demand more complicated, particularized and flexible analysis; while reducing costs and enhancing predictability require broader and simpler rules.

But just as the distinctions in the preceding sections turned out to be less robust and more contingent than commonly supposed, the idea of a necessary tradeoff between right answer and systemic values is overblown. It is, I think, in large part the product of the particular history of American choice of law. As a way to see that contingency, I now turn to the history.

context what it supports is a broad ability to choose the governing law, which promotes systemic values of certainty, predictability, and uniformity.

46 Restatement, Second, $\S 5$, cmt d. In comment b on $\S 145$, the Second Restatement suggests that the Section 6 factors can also be "divided into five groups," which include interstate relations, state policies, party interests, basic policies, and judicial administration. This chops too finely, in my view: interstate relations, state policies, party interests and basic policies can all most usefully be considered factors related to the right answer to a choice of law problem.

47 What is the right answer to a choice of law question? This is a complex and difficult question, but this chapter does not depend on any particular answer. The main theoretical division is between those who remain agnostic about substantive values and view the role of choice of law as allocating authority among co-equal sovereigns and those who believe that choice of law should be used to advance favored substantive values, such as efficiency or justice. See, for example, Andrew T. Guzman, Choice of Law: New Foundations, 90 Geo. L. J. 883 (2002) (arguing that choice of law should be used to promote efficiency); Erin A. O'Hara and Larry E. Ribstein, From Politics to Efficiency in Choice of Law, 67 U. Chi. L. Rev. 1151 (2000) (same); Friedrich K. Juenger, Choice of LAW And Multistate Justice (1993) (arguing that choice of law should be used to favor best substantive law). I tend to fall on the former side, though I believe in a limited role for outcome-influenced choice of law rules. See Symeonides, supra note 22 , at 402-11 (discussing "conflicts justice" vs. "material justice").

48 In theory, of course, there need not be. A perfect rule would get all the cases right while being easy to apply. 


\section{THE U.S. HISTORY AND THE EUROPEAN APPROACH}

\subsection{The First Restatement}

The First Restatement is the paradigm example of one side of the conventional choice of law dichotomies: it is traditional, territorial, rule based and inflexible (absent deliberate manipulation). This might look like a choice to favor what I have called systemic factors, but the truth is a bit more complicated - the First Restatement is both better and worse than that description suggests. If you accept the territorial premise, it is better - perhaps ideal, or at least unimprovable. It generates correct answers, because its answers are the only ones possible. And it does so in a rule-based way that will produce a fair amount of uniformity, simplicity and predictability - though only a fair amount, because the First Restatement is massively complex and can be quite difficult to apply. ${ }^{49}$ But again, accepting the territorial premise, it may be that things just cannot be made simpler: Joseph Beale is telling us not the way things should be, but the way they are.

If you do not accept the territorial premise, however, the First Restatement does just about everything wrong. Its rules generate arbitrary results (arbitrary from the perspective of policy analysis) in at least some cases. ${ }^{50}$ But because the results are presented as ineluctable consequences of the nature of law, the First Restatement had no way to reject them on the grounds of their arbitrariness. Instead, judges avoided the results by manipulating the system: they used escape devices. ${ }^{51}$ This tactic advanced "right answer" factors, but at the cost of systemic ones: because the resort to escape devices was not explained in terms of the real factors behind it, it necessarily reduced uniformity, predictability and ease of application.

The First Restatement, in short, manufactured a conflict between systemic and right answer factors. It had overbroad rules that generated bad results, and it lacked a way of talking about why the results were bad or how to avoid them in a way that was responsive to the real underlying concerns. That lack was what created the conflict: when courts avoided the arbitrary results, they could do so only in a way that reduced certainty, predictability and uniformity.

These failures made it obvious that the First Restatement could be improved. One could, for instance, narrow the rules that produced the arbitrary results, the defects that impelled judges to invoke escape devices. One could write new rules for those cases rules that were based on the appropriate considerations and delivered sensible results. In order to do that, of course, one would have to know what those considerations were. They could not be found by reasoning deductively from first principles; that was Joseph Beale's mistake. They would have to be uncovered by analysis of judicial decisions: by

49 Those who advocate for territoriality on the basis of its systemic factors (simplicity, predictability, uniformity) should spend some time reading the entirety of the First Restatement.

50 Famous examples include Carroll v. Great Southern Railroad, 11 So. 803 (Ala. 1893). In teaching the traditional approach, casebooks tend to focus on such cases without inquiring how often they occur in practice, which may overstate the perversity of the First Restatement's rules.

51 See, for example, Levy v. Daniels' U-Drive Auto Renting Co., 143 A 163 (Conn. 1928) (using characterization escape device). 
figuring out what was really motivating the judges in the cases in which they used escape devices. And that would require a way to allow or encourage judges to explain themselves, to make decisions transparently, talking about the factors that were actually relevant to a choice of law decision and showing how they balanced those factors against each other.

Is that what happened? We'll see. For now, it suffices to note that the First Restatement did create a necessary tradeoff between systemic and right answer factors. Not coincidentally, it was, by most measures, a failure. It could be said to have lasted 37 years - it was published in 1934 and the Second Restatement was not completed until 1971 - but that figure is probably misleading. The Second Restatement took 17 years to complete, so the American Law Institute had conceded the need for a new Restatement only 20 years after publication of the First. ${ }^{52}$ Moreover, the First Restatement was attacked from its inception, fiercely and quite successfully. ${ }^{53}$ Realists such as David Cavers and Walter Wheeler Cook, writing in the 1930s, discredited its intellectual underpinnings among many, if not most, academics and judges. ${ }^{54}$ The First Restatement enjoyed at best a brief reign before the revolution that led to the Second Restatement.

\subsection{The Choice of Law Revolution and the Second Restatement}

The pervasive sense that there is a necessary tradeoff between systemic and right answer factors may come in part from the contingent fact that there was indeed such a tradeoff in the First Restatement. It may also come in part from the contingent fact that the most influential of the revolutionaries, Brainerd Currie, focused on right answer factors while seeming indifferent to systemic ones. Currie's solution to true conflicts and unprovided-for cases, for instance, was to use forum law. ${ }^{55}$ Forum preference obviously imposes massive systemic costs: it destroys uniformity and also certainty and predictability viewed from the time of relevant conduct. It does not do this in order to advance right answer factors in any substantial way - it is indifferent to which state's interest is more substantial, selecting forum law whenever the forum is interested. And if we broaden our understanding of state policies beyond those underlying a particular law, it cannot be justified at all in policy terms without some explanation of why states would not care about systemic values. Currie never gave that explanation. Instead, like Beale, he seemed to assume that things could not be otherwise: courts lack the authority to resolve true conflicts or depart from forum law if the forum is interested. ${ }^{56}$

52 Twenty years is a long time, but not compared to the reign of the Second Restatement: the American Law Institute did not decide to begin work on a Third Restatement until 2014, 43 years after publication of the Second Restatement.

53 See, for example, Kermit Roosevelt III, The Myth of Choice of Law: Rethinking Conflicts, 97 Mich. L. Rev. 2448, 2458-61 (1999) (discussing criticism of First Restatement).

54 See ibid.

55 See Brainerd Currie, Selected Essays on the Conflict of Laws 181-82 (1963).

56 See ibid. ("[A]ssessment of the respective values of the competing legitimate interests of two sovereign states ... is a political function of a very high order. This is a function that should not be committed to courts in a democracy.") Currie did at least acknowledge the criticism. See id. at 186 ("I have been told that I give insufficient recognition to governmental policies other 
In consequence, interest analysis too seems to suggest a necessary tradeoff between right answer and systemic factors.

And what about the Second Restatement? It departed radically from the First: rather than rules telling courts which state's law to choose, it offered the factors in Section 6: an open-ended list of things to keep in mind, with no explanation of their relative weight or how to resolve conflicts between them. ${ }^{57}$ Later sections did have what looked like rules, but these were generally not First Restatement-style directives; they were merely predictions about how the Section 6 analysis would usually come out in certain kinds of cases. ${ }^{58}$ In consequence, courts were required to do the analysis more or less from scratch in each case. In terms of right answer versus systemic values, the Second Restatement seems to flop all the way over to right answers: it gives courts all the necessary tools but then, out of a fear of saying something too restrictive, never explains how to use them. ${ }^{59}$

Academic reaction was harshly negative. ${ }^{60}$ It is commonplace now to describe the Second Restatement as an overreaction to the failures of the First: a wild lurch away from excess rigidity to excess flexibility. ${ }^{61}$ The conventional understanding of the American experience is that it demonstrates the necessary tradeoff between systemic and right answer values. The First Restatement privileged the former and the Second Restatement the latter. Each went too far. ${ }^{62}$

than those that are expressed in specific statutes and rules ...") His answer was that he felt it necessary to "first clear away the apparatus that creates false problems and obscures the nature of the real ones." Id. at 187. This suggests that Currie might well have been accepting of policy-conscious rules.

57 See Reese, supra note 1, at 315 (describing Section 6 factors as an approach).

58 The Restatement itself, in fact, explicitly disavows the "rule" label. See Restatement, Second, of Conflict of Laws at vii-viii (describing these statements as "empirical appraisals rather than purported rules." With some kinds of issue - for instance, property and substance/ procedure characterization - the Second Restatement did offer real rules. See, for example, $\S 126$ (stating that forum law determines issues about notice and process). But these are not the areas of choice of law that have attracted the most academic attention. In those areas - torts and contracts - the Second Restatement resolutely refuses to tell courts the answer to choice of law questions.

59 As I once put it, "For almost any choice-of-law problem, the Second Restatement holds the correct answer. The problem is that it also holds seven or so other answers, depending on how the analysis is performed." Kermit Roosevelt III, CONFLICT OF LAWS: CONCEPTS AND INSIGHTS 90 (2nd ed. 2015).

60 See Roosevelt, supra note 53, at 2466.

61 See Symeonides, supra note 22, at 419 (stating that "American conflicts law has careened from the one extreme of the rigidity of the 1930s to the other extreme of the total flexibility or anarchy of the conflicts revolution, when rules were denounced and legal certainty was demoted to a low-rank goal.”).

62 See ibid. (asking "Did the American movement toward flexibility go too far?"); id. at 423 ("in its zeal to cleanse the system from all the vestiges of the first Restatement, the revolution went too far in denouncing all choice-of-law rules"); id. at 425 ("It is also time to recognize that the revolution has gone too far in embracing flexibility to the exclusion of all certainty, just as the traditional system had gone too far toward certainty to the exclusion of all flexibility"). 
That's what I learned as a student; that's what I repeated as a young scholar. ${ }^{63}$ But I have come to think that this reaction seriously misunderstands both the First and the Second Restatements. As I already suggested, the First Restatement looks somewhat different if you take Beale's perspective. If territoriality is part of the nature of law, it cannot be a bad choice or a miscalibrated tradeoff. There is no choice involved, no possibility of striking a different balance. There may be some ways in which the First Restatement is not good, but there is no way in which it could be better.

Beale was wrong, of course. Territoriality is not a metaphysical necessity and the First Restatement could have been much better. When we look back on the First Restatement now, we see things he did not. Some contemporaneous critics did see those things, of course, but we still err if we suppose that the deficiencies of the First Restatement were visible from his perspective.

What about the Second? In recent years, I have come to think that in the same way that the First Restatement looks different if you understand the perspective of its Reporter, the Second Restatement does too. But that is not because Willis Reese had a mistaken belief about the nature of law; it is because he had a true belief about the nature of judicial decision making. It is not because we see things he did not; it is because we have lost sight of things that he saw clearly. I will discuss Reese's perspective and hopes for the Second Restatement in a subsequent section. As a way to build towards it, I now want to briefly consider the European experience.

\subsection{The European Experience}

While adventurous courts and scholars were revolutionizing American choice of law, things in Europe proceeded more calmly. ${ }^{64}$ Like the American ancien regime, the

63 In my first article about choice of law, I wrote that the Second Restatement "synthesiz[ed] a wide range of insights into an indigestible stew." Roosevelt, supra note 53. I was participating in what seems almost a competition among scholars to come up with the most colorful put-down. Compare Larry Kramer, Rethinking Choice of Law, 90 Colum. L. Rev. 277, at 321-22 n.149 ("no explanatory power"); Douglas Laycock, Equal Citizens of Equal and Territorial States: The Constitutional Foundations of Choice of Law, 92 Colum. L. Rev. 249, 253 ("Trying to be all things to all people, [the Second Restatement] produced mush."); Joseph William Singer, Real Conflicts, 69 B.U. L. Rev. 1, 77 (1989) ("mystifies rather than clarifies"); Jeffrey M. Shaman, The Vicissitudes of Choice of Law: The Restatement (First, Second) and Interest Analysis, 45 Buff. L. Rev. 329 (calling the Second Restatement "a strange brew ... rife with inconsistency, incongruence, and incoherence"). Judges have also gotten in on the act. See, for example, Paul v. National Life, 352 S.E.2d 550 (W. Va. 1986) ("That sounds pretty intellectual, but we still prefer a rule.”); Dowis v. Mud Slingers, 621 S.E.2d 413, 417-18 (Ga. 2005) (describing the Second Restatement as "dominating the field while bewildering its users). All of this sounds a bit juvenile to me now, reminiscent of the glee with which critics mocked Joseph Beale. See generally Symeon C. Symeonides, The First Conflicts Restatement Through the Eyes of Old: As Bad as Its Reputation?, 32 S. Ill. L. J. 39, 39 (2007) (noting that Beale "has been the target of ridicule by practically every conflicts writer in the last four decades"). More importantly, I believe it rests on a misunderstanding of what the Second Restatement was supposed to do.

64 For a discussion of the American and European experiences offering essentially the same perspective developed here, see generally Symeonides, supra note 22 at 412-19. 
Europeans had rules, but they were not presented as metaphysical necessities. In consequence, their displacement did not require a violent and total overthrow. The change was not "impulsive, rash, and wholesale," but "careful, reserved, and respectful." 65 The Europeans also benefited, perhaps, from the fact that their modifications tended to follow the American choice of law revolution. 66 They were able to identify the relatively small number of cases in which the modern analysis was unambiguously superior to the traditional and to incorporate those cases as exceptions to traditional rules. Thus, Europeans confronting broad and rigid lex loci rules tended to calmly add exceptions for certain categories of cases, such as some common-domicile cases.

Europeans followed a different path than Americans did from traditional to contemporary choice of law systems. Contemporary European systems look different from contemporary American systems - and even more different from "modern" American systems. But there is nonetheless a substantial degree of convergence in terms of results. In tort conflicts, for instance, codifications overwhelmingly favor territorialism. They do, however, recognize the most widely accepted exception: certain kinds of common domicile cases. ${ }^{67}$ The European Union's Rome II regulation, for instance, offers lex loci delicti as a general rule, ${ }^{68}$ then provides an exception for (apparently) all cases in which habitual residence is shared, ${ }^{69}$ and then qualifies the resulting rule/ exception structure with a further escape clause for torts "manifestly more closely connected" with another country 70 and an admonition to take account "so far as is appropriate" of the rules of safety and conduct in force at the place of the relevant event. $^{71}$

To the extent that the American choice of law revolution offered insights that are now widely accepted in American courts - the main one being some sort of common domicile exception to lex loci delicti - European systems have managed to incorporate those insights, whether by learning from the Americans or arriving at them independently. ${ }^{72}$ On the more general question of certainty versus flexibility, or right answers

65 Id. at $412-13$.

66 Id. at 414. The extent to which American thinking actually affected the evolution of European rules is unclear and contested. Some scholars suggest that the influence was minimal. See, for example, Celia Wasserstein Fassberg, Realism and Revolution in Conflict of Laws: In with a Bang and Out with a Whimper, 163 U. Pa. L. Rev. 1919, 1920 (2015) (claiming that American scholarship had a "striking impact on judicial practice in the United States and [an] equally striking absence of almost any impact on scholarship or judicial practice outside the United States"); id. at 1932 (stating that "the vast and prolific American literature on choice of law methodology was widely read and widely cited by scholars, legislators and courts outside the United States, but was wholeheartedly and unequivocally rejected by them"). But see Symeonides, supra note 22, at 413-14.

67 See generally Symeonides, supra note 24, at 72-80 (discussing common domicile exceptions in codifications).

68 Rome II, Article 4(1).

69 Id. Article 4(2).

70 Id. Article 4(3).

71 Id. Article 17.

72 Investigating the timing of alterations to European codifications relative to the American choice of law revolution might clarify the existence of a causal relationship. At least, if the Europeans moved first, they could more plausibly claim not to have benefited from the American 
versus systemic values, Europeans have also changed their systems to incorporate escape clauses that allow judges to depart from the rules when following them produces an unacceptably arbitrary result. ${ }^{73}$

There are two important things to take from the European experience. First, in terms of substance, things have gone very similarly to the way they did in America. ${ }^{74}$ Particular exceptions have been codified, and the possibility of unforeseen cases where rules produce arbitrary or incorrect results has been accommodated via escape clauses. Second, while the American experience is generally considered a wild oscillation, the European experience looks like progress.

Why is this? One answer would be that the American movement was so extreme. Brainerd Currie famously said that we would be better off without choice of law rules. ${ }^{75}$ And the Second Restatement is so under-determinative that it is all but useless as a guide. But possibly this perspective misunderstands the goals of the Second Restatement. Possibly Willis Reese had a vision of progress that could make the American experience more like the European. The next section considers that possibility.

\subsection{The Second Restatement Reconsidered}

The conventional wisdom about the Second Restatement, I have said, is that it is mush. ${ }^{76}$ Reacting to the rigidities of the First Restatement, and under the influence of radicals who argued against the very idea of choice of law rules, it swung all the way to a wildly undeterminative approach. ${ }^{77}$ That flexibility made it appealing to judges, since it allowed them to reach results they deemed sensible; but it cast away the systemic values we associate with rules, certainty and the traditional approach. As a

revolution. The issue is of marginal relevance to this chapter, but my sense is that the Europeans did follow the Americans chronologically and were aware of American thinking. See E. Jayme, The American Conflicts Revolution and Its Impact on European Private International Law, in Forty YeArs On: The Evolution of Postwar Private InTERnational LaW In Europe, 22 (1992) (suggesting that perhaps "European judges took advantage of the fact that they were to decide later than their American colleagues"); Fassberg, supra note 66, at 1932 (stating that that "the vast and prolific American literature on choice of law methodology was widely read and widely cited by scholars, legislators and courts outside the United States"). Fassberg goes on to claim that American thinking "was wholeheartedly and unequivocally rejected" by Europeans, see ibid.; but this claim is hard to square with the fact that European codifications moved in the direction suggested by American theory, notably in terms of modifying territoriality with an exception for common domicile cases.

73 These escape clauses may not be ideal - Rome II's failure to go issue by issue makes its escape clause harder to invoke and more extreme in its effect - but they are a recognition of the need for some discretion. See Symeon C. Symeonides, The American Revolution and the European Evolution in Choice of Law: Reciprocal Lessons, 82 Tul. L. Rev. 1741, 1774 (2008)

74 See Symeonides, supra note 24 at 415.

75 Currie, SEleCted EsSAYS, at 180-83.

76 Laycock, supra note 63, at 253.

77 See, for example, Glenn S. Koppel, The Functional and Dysfunctional Role of Formalism in Federalism: Shady Grove versus Nicastro,16 Lewis \& Clark L. Rev. 905909 (describing the Second Restatement as "under the influence of legal realists like Brainerd Currie"). 
result, it too can be considered a failure: despite wide acceptance by states, it lacks a theory that would satisfy academics. And indeed, academics attacked the Second Restatement fiercely even before it was completed. ${ }^{78}$

Not all judges are fans either: the Second Restatement demands a lot of them and, as a result, sometimes works poorly in practice. ${ }^{79}$ At best, it requires courts to reinvent the wheel, performing the Section 6 analysis anew in each case. At worst, it invites error, laziness, or the inevitable inconsistencies that arise when generalist judges infrequently apply such an open-ended approach. ${ }^{80}$ What is most surprising about the Second Restatement is that it has lasted as long it has.

Listening to this conventional account, it is not hard to hear echoes of the standard account of the First Restatement. The First Restatement, remember, was attacked almost from its inception. It was unpopular with academics. It erred by swinging too far to one side of the certainty/flexibility divide.

That view of the First Restatement, I've suggested, isn't quite fair - it's not fair, at least, if one takes the perspective of Joseph Beale. How about the Second Restatement? It's true that the Second Restatement demands a lot of judges - they are supposed to consider all the Section 6 factors, and any others that come to mind, and to balance them sensibly in almost every case. ${ }^{81}$ It is true that this kind of system should not last long. ${ }^{82}$ But did Willis Reese not see those points?

In fact, he did. Willis Reese did not believe that the Section 6 balancing was a good way for courts to resolve choice of law cases on an indefinite basis. ${ }^{83} \mathrm{He}$ believed that rules were preferable. ${ }^{84}$ But he also realized that such rules, to be sensible, would have to be based on an assessment of the factors relevant to a choice of law decision. And to be part of a Restatement, they would have to be based on judicial practice. Writing such rules, then, required a body of judicial decisions that candidly and sensibly discussed what factors were relevant to choice of law and how they should be balanced against each other in particular cases. No such body of judicial decisions existed when the Second Restatement was being drafted. ${ }^{85}$ And what Reese set out to do, essentially, was to create it.

78 See, for example, Albert A. Ehrenzweig, The Second Conflicts Restatement: A Last Appeal for its Withdrawal, 113 U Pa. L. Rev. 1230 (1965); see generally Shaman, supra note 63 (noting criticisms).

79 See cases cited supra note 63.

80 See Russell J. Weintraub, The Restatement Third of Conflict of Laws: An Idea Whose Time Has Not Come, 75 Ind. L. J. 679, 679-80 (2000).

81 See Symeonides, supra note 22 at 423-24 (stating that "When each case is decided ad hoc as if it were a case of first impression, multiple problems arise, including increased litigation costs, waste of judicial resources, and increased danger of judicial subjectivism").

82 Id. at 425 (stating that "transitions and experimentations should not last forever" and that "four decades after the revolution began, it is high time to see how it should end").

83 Willis L.M. Reese, The Second Restatement of Conflict of Laws Revisited, 34 Mercer L. Rev. 501, 519 (1983) (describing Second Restatement as a "transitional work").

84 See Willis L. M. Reese, Choice of Law Rules or Approach, 57 Cornell L. Rev. 315 (1972).

85 See Willis L. M. Reese, Conflict of Laws and the Restatement Second, 28 Law and Contemp. Probs. 679, 681, 699 (1963) (stating that "[c]hoice of law, even now, is not ripe for 
This perspective explains why the Second Restatement, particularly in its torts and contracts chapters, has less the feel of a set of instructions for judges than that of an invitation to them: take these considerations and show us how you decide cases. ${ }^{86}$ What Reese hoped was not that the Second Restatement would last indefinitely as an approach conferring nearly unbounded discretion, ${ }^{87}$ but that experience applying it would generate data that could be used to draft narrow and policy-sensitive rules. That was his idea of progress.

Such progress has in fact occurred in the United States. The first example might be New York's adoption of the Neumeier rules. These rules, which attempted to systematize the resolution of cases involving loss-allocating rules, have faced serious criticism on the grounds that they do not always deliver right answers. (Basically, the Neumeier rules amount to interest analysis with a territorial tiebreaker: they resolve false conflicts correctly, but rather than seeking some sort of right answer to true conflicts, they invoke territoriality as a deciding factor.) As Jeffrey Shaman puts it:

the New York Court of Appeals began to construct a logical system based on interest analysis to make choice of law decisions. Subsequently, however, the Court of Appeals spoiled its earlier efforts by inexplicably reverting ... to a rule-oriented approach partially based on territoriality and diverging from interest analysis. ${ }^{88}$

A leading casebook calls Neumeier and its aftermath "The New York Mess."89

But is the turn to territoriality inexplicable? It is possible to try to get the right answer to true conflicts. California's comparative impairment approach is probably the most theoretically sophisticated way to do so. If performed correctly, comparative impairment does a very good job of delivering right answers. But precisely because of its sophistication, it is hard to perform correctly. The consequence, at best, is a lack of predictability and ease of application; at worst, the difficulty leads to errors, with costs in uniformity and even right answers. The game may not be worth the candle.

What is the alternative to pursuing right answers at all costs? It is to consider systemic factors and adopt a rule, even if the rule is not perfect. (Reese said this explicitly. $)^{90}$ Better if the rule represents consensus, which the Neumeier rules do; ${ }^{91}$

restatement" and so "the more general and more flexible formulation of "state of most significant relationship' has been resorted to").

86 This invitation to candor is the payoff of the realist attack on the First Restatement: if the rules set out in a body of law do not explain the outcomes of judicial decisions, the first step is to identify the factors that really drive judicial behavior. See Kermit Roosevelt III, Legal Realism and the Conflict of Laws, https://scholarship.law.upenn.edu/faculty_scholarship/1582/. The second step is to draft rules that capture those factors. See id.

87 The discretion offered by the Second Restatement may also be overestimated: careful attention to the comments and an understanding of the underlying theories produces more guidance than is commonly supposed. See generally Harold P. Southerland, A Plea for the Proper Use of the Second Restatement of Conflict of Laws, 27 Vt. L. Rev. 1 (2002).

88 Shaman, supra note 63.

89 See Herma Hill Kay, Larry Kramer, Kermit Roosevelt \& David Franklin, Conflict of LAWS: CASES-COMMENTS-QUESTIONS 209 (10th ed. 2018).

90 See Reese, supra note 1 at 322 ("Perfection is not for this world. The advantages which good rules bring are worth the price of an occasional doubtful result."). 
better still if it aligns in many cases with the best courts can do under the complicated right answer approach. ${ }^{92}$ And that is what the Neumeier court, quite self-consciously, set out to do: it decided that there had been enough experience with modern analysis to craft an appropriately narrow and policy-based rule, which could go far enough in terms of promoting right answer values while (finally!) turning back to the systemic factors that the policy analysis neglected. As Chief Judge Fuld wrote, "There is ... no reason why choice of law rules, more narrow than those previously devised, should not be successfully developed, in order to assure a greater degree of predictability and uniformity."93

That is progress, and it has not been limited to New York. With the guidance of Symeon Symeonides, Louisiana and Oregon have adopted choice of law codifications what William Richman describes as "smart empirically derived conflicts rules" which reproduce the right answers judges have converged on over the years. ${ }^{94}$ All of these developments are fulfilling the basic hope of Willis Reese: that experience seeking right answers under open-ended balancing approaches would provide data that would allow the drafting of narrow, policy-sensitive rules. The crafting of such rules allows us to advance right answer and systemic factors simultaneously.

\section{THE U.S. FUTURE: TRANSCENDING FALSE DICHOTOMIES}

The main argument of this chapter is that the choice between certainty and flexibility, or rules and standards or approaches, is not as important as it is generally portrayed. Neither side of these dichotomies has intrinsic value. We discuss them mostly as ways to attain other values - what I have called the systemic and right answer values.

What that means is that choice of law systems should be evaluated not in terms of their certainty or flexibility, or whether they consist of rules or approaches, and so on. They should be evaluated in terms of the degree to which they advance systemic and right answer values.

That is not so much a question of the form they take as of how good they are. There are good rules and bad rules, good approaches and bad approaches. Overall, we should aspire to have a choice of law system that is good, rather than bad.

It is, happily, possible to get a little more specific than that. While there may not be a necessary tradeoff between systemic and right answer values, there are certain things that make them easier or harder to pursue. Rules, unless they are very bad rules, do tend to promote systemic factors like uniformity and predictability. Rules, in my

\footnotetext{
91 See Symeonides, supra note 22, at 123-259 (documenting convergence).

92 This is the import of Hoffheimer's study of California cases. See Michael H. Hoffheimer, California's Territorial Turn in Choice of Law, 67 Rutgers U. L. Rev. 167 (2015).

93 Neumeier, 286 N.E.2d 454, 457 (N.Y. 1972).

94 See William M. Richman, A New Breed of Smart Empirically Derived Conflicts Rules:
} Better Law Than "Better Law" in the Post-Tort Reform Era: Reviewing Symeon C. Symeonides, the American Choice-of-Law Revolution: Past, Present and Future (2006), 82 Tul. L. Rev. 2181, 2191 (2008). 
judgment, are to be preferred, unless they impose unacceptably high costs in terms of right answer factors. Whether they will do so or not is a question about the content of the rules.

The way to draft good rules is now relatively clear. The rules should be narrow, with a flexible residual approach handling cases not governed by rule. They should be sensitive to the content of laws and the policies of affected states. They should be derived from the practice of courts. They should have escape clauses that allow departure in case of serious error. Both the rules and the escape clauses should be derived from an overarching methodology that allows users of the rules to understand what they were designed to achieve and, correlatively, to identify instances in which they fail to achieve those ends. ${ }^{95}$

The possibility of good rules shows us, in my view, that the traditional dichotomies of choice of law are largely false. The tradeoffs they suggest are either illusions or irrelevancies: what we care about are the two sets of values and it is possible to advance both at the same time.

Symeon Symeonides describes the quest for good rules as seeking "a new and proper equilibrium between the perpetually conflicting needs for certainty and flexibility." 96 As the above discussion should demonstrate, I conceptualize the purported conflict somewhat differently. But I end in the same place. A good set of rules can, as he wrote of the Louisiana codification:

combine ... the best elements from the vast laboratory of the American interstate conflicts experience, Louisiana's civil law heritage, and Europe's rich codification tradition, while also charting an independent new course; compress ... the lessons of the American choice-of-law revolution into succinct, civilian-style rules and combine ... them with a flexible Americanstyle "approach"; and provide ... more certainty than the conflicts laws of any other state of the United States and more flexibility than any European conflicts codification. ${ }^{97}$

I will not go into the details of the Third Restatement of Conflict of Laws, currently in progress, but I will say that Symeonides' assessment strikes me as the target to aim for.

\section{CONCLUSION}

In this chapter, I have argued for three main propositions. First, we use the traditional dichotomies of choice of law theory (certainty versus flexibility, rules versus standards or approaches, traditional versus modern and territorial versus policy-based) as proxies for certain clusters of values. No one really cares about either side of the dichotomy for its own sake; they are important because they make it easier or more difficult to promote the sets of values I have called "right answer" and "systemic" values.

95 See id. at 1919-20; see also Symeonides, supra note 22, at 428, 435-37 (setting out guidelines for drafting choice of law rules).

96 Symeon C. Symeonides, The Choice-of-Law Revolution Fifty Years After Currie: An End and a Beginning, 2015 U. Ill. L. Rev. 1847, 1916 (2015).

97 Symeon Symeonides, The Conflicts Book of the Louisiana Civil Code: Civilian, American, or Original, 83 Tul. L. Rev. 1041 (2009). 
Second, while the traditional dichotomies usually work well enough as proxies, their connection to the two clusters of values is contingent and weaker than usually supposed. And while framing the issue in terms of dichotomies is adequate for most purposes, it has a serious drawback. The sides of the dichotomies superficially seem and to some extent, really are - mutually incompatible. It is quite hard, perhaps impossible, to simultaneously increase certainty (understood as an absence of judicial discretion) and flexibility (understood as the presence of judicial discretion). It is probably impossible to make a system simultaneously more rule bound and more standard governed. It is hard, likewise, to make it both more territorial and more policy focused.

But matters are quite different with respect to the two sets of values. It is absolutely possible to take a system that delivers right answers in a certain proportion of cases and delivers them with a certain degree of simplicity, ease and predictability, and to improve it on both dimensions. It is absolutely possible to make a system better in terms of both right answer and systemic values. There is no necessary tradeoff between the clusters of values, and to the extent that using the dichotomies as proxies for those clusters makes us think there is, it misleads us.

Third, the dichotomies warp our understanding of both the history of choice of law and its future. Thinking in terms of rules versus approaches, for instance, we tend to think of European choice of law as relatively consistently rule based, with some movement toward standards and American choice of law as oscillating wildly from the rules of the First Restatement to the unconstrained discretion of the Second. Neither description suggests much progress: there is lateral movement along the spectrum from rules to approach; there is what seems like an endless cycle, but there is no concept of a forward dimension.

If, however, we think in terms of right answer and systemic values, we can see how the European modifications have improved their systems on both counts: that is progress. Perhaps more important, we can see how the Second Restatement was intended not as a permanent solution, an approach to be used indefinitely, but as a means of generating data about right answers that could be used as the basis for drafting rules. The fact that Willis Reese's repeated statements to this effect dropped almost entirely out of American choice of law scholarship and analysis of the Second Restatement says something about the distorting influence of the dichotomies on American thought. It also says something about the way forward: a well-designed system of narrow rules, with appropriate escape clauses, could improve American choice of law in every way. 